\title{
Economic Space Transformation in a Stagnant Economy
}

\author{
Michail Nikolaev \\ Department of Economics, Finance and Financial Law \\ Pskov State University \\ Pskov, Russia \\ mihaelnikolaev@mail.ru
}

\author{
Marina Makhotaeva \\ Department of National Security and Human Rights \\ Pskov State University \\ Pskov, Russia \\ makhotaeva@mail.ru
}

\begin{abstract}
The economic space quality is an important factor for the sustainable and stable development of regions. The period of stagnation of the Russian economy has had a negative impact on the dynamics of the social and economic development of the Northwest Federal District regions. The significant decline in GRP growth and fixed investment was accompanied by a significant increase in interregional differentiation, which further increased the heterogeneity of economic space. A sharp decline in the indices of «weak» regions has led to an increase in the tendency of «shrinking» of the population to sufficiently well-off regions, which creates a multiplicative effect of the increase of differentiation of the level of social and economic development of the RF subjects and further deterioration of the economic space quality. «New» factors of regional development - innovations and digitalization, do not yet have a significant impact on regional development due to their weakness. The quality of economic space is also affected by a significant reduction in interregional interaction in a stagnant economy.
\end{abstract}

Keywords-investment, innovation, labour, economic space, region, interregional interaction.

\section{INTRODUCTION}

The territorial factor is essential not only for the development of the regions, but also for the state as a whole, since in the coordinates of the space "population - economy territory" are the main processes of the activity of the society[1]. The spatial dimension of social and economic development is given priority in regulatory and planning documents. The Economic Security Strategy of the Russian Federation for the period up to 2030 considers the unity of the economic space together with economic sovereignty as an attribute of the economic security of the state. At the same time, the uneven spatial development of the Russian Federation in terms of the level and pace of socio-economic development is noted as a threat to economic security. On this basis, balanced spatial and regional development has been identified as one of the objectives of the state economic security policy. The high level of interregional social and economic inequality is also identified as a major problem in the Spatial Development Strategy of the Russian Federation up to 2025. Statistics confirm the relevance of this problem. For example, in 2018, fixed capital investment per capita in the Tyumen region amounted to 627,473 roubles and in the Republic of Ingushetia - 44,814 roubles. There is also a significant difference between the regions of the same Federal District. For example, in the Leningrad region the value of the indicator was 255,016 roubles and in the neighbouring Pskov region - 49,520 roubles. Other key social and economic indicators also show high levels of differentiation.

According to the authors of the paper [2], the existence of many economically weak, depressed territories leads to the reduction of Russia's global competitiveness and its displacement to the periphery of the world economy. One of the main problems of the spatial development of the Russian Federation is the high level of differentiation in the social and economic development of the constituent entities of the Russian Federation, which hampers the realization of the potential of interregional interaction. At the same time, ensuring spatial balance is an important factor in improving the dynamics of the domestic economy, enabling it to strengthen its competitive position in external markets and to ensure the national security of the country [3]. According to the authors of the paper [4], insufficient use of the potential of most territories is one of the reasons for the transition of the economy of the Russian Federation to stagnation in 20132014. Improving economic performance therefore requires more effective use of the potential of the regions.

In order to achieve the objective of balanced spatial development, the Economic Security Strategy envisages a number of objectives. These include the reduction of the level of interregional differentiation in the social and economic development of the constituent entities of the Russian Federation, the expansion and strengthening of economic ties between regions, and the creation of interregional clusters.

At the same time, given the objectively valid laws of the market economy and the virtual absence of the state regional policy, spatial imbalances are further deepening [5]. For example, the spatial distribution of industry in the NorthWest is influenced by the system-wide trend of polarization of regional development, which results in the concentration of economic activity within the territory of influence of the 
Saint Petersburg agglomeration, as well as the continuing role of the commodity sector in the development of industry.

The polarization of territorial development under conditions of low level of inter-regional cooperation leads to a growing fragmentation of Russian economic space.

The following factors also contribute to this trend:

- Low density of the population;

- Large areas with poor infrastructure;

- Weak institutional environment;

- A high level of regional differentiation to prevent diffusion of innovation from centre to periphery;

- Uneven economic growth in Russian regions [6].

The task of improving the quality of economic space brings up to date the problem of analysing the essence of the concept and its main characteristics. The paper [7] highlights the following approaches to defining economic space: territorial, process, information, management, resource and institutional. From the point of view of analysing the problems of spatial development, it is useful to take a territorial approach, whereby the economic space is defined as a saturated territory that contains many objects and links between them: settlements, industrial enterprises, economic and recreational areas, transport and engineering networks, etc. [8]. The transformation of the social and economic space means significant changes in the physical location of the infrastructure, economy and population of a region, as well as changes in the characteristics of its institutional environment [9].

Spatial transformation factors include: migration of capital and labour, scientific and technological development, structural changes in the economy, long periods of economic stagnation, changes in the institutional environment [10].

The transformation of the economic space is primarily driven by the flow of investment. The paper [11] examines the determinants of foreign investment flows to the regions. At present, these inflows are largely dependent on the level of investment potential of the region. Herewith, the differences in individual regional risks are not significant because of the high risks posed by the national economy as a whole.

The quality of the economic space is closely linked to the sustainability of the regional system. In the programme documents of the constituent entities of the Federation, sustainable development is linked to the transition to an innovative model of the economic development. Cluster initiatives in particular are recommended as a tool for sustainable development. At the same time, the analysis of social and economic processes reveals the low level of innovation in the regions and its weak impact on the sustainability of the economy. Thus, the innovation strategy should be seen as a promising direction for the sustainable development of the regions [12,13].

Regional development institutions are an important element of institutional infrastructure. Project management organizations and development agencies are considered the most effective [14, 15]. Based on the experience of other countries, these institutions can have a significant impact on the transformation of the economic space of cities and regions. At the same time, according to the authors, in the Russian Federation they have not yet been able to realize their mission as a driver of regional development.

In the new economy, the processes of creating the digital space of the national economic system have a major impact on the processes of economic transformation. The study of the impact of digitalization on changes in the spatial organization of the national economy has been carried out in [16]. The most successful digital transformation processes are taking place in regions with high levels of social and economic development. At the same time, the processes taking place in these regions are not conducive to increasing the digital divide in the weaker regions. As a result, there has been a significant outflow of highly skilled personnel to highly developed regions, leading to a further increase in the economic space differentiation [17].

In the modern economy, partnership networks play a significant role in innovation. Clusters and technology platforms provide an enabling environment for innovation networks. An important factor in the formation of innovation networks is the complementarity of the capacities of its participants. The technological platforms that form the technological basis for interaction among the participants of the network are provided by the enterprise information network $[18,19]$.

Thus, the processes of economic transformation are influenced both by traditional factors, which primarily include labour and capital, and by the new, evolving processes of the digital economy.

\section{METHODS}

The object of the paper is to analyse the processes of transformation of the economic space in a period of stagnation of the economy. The study focuses on the regions of the Northwest Federal district and the subject of the paper is the territorial aspects of social and economic processes. The methodology of the research includes the analysis of domestic and foreign literature on factors of economic transformation. The methods used in the research are: integrated statistical data analysis, correlation analysis, comparative analysis of different theoretical concepts, grouping method, and systematization of research results.

\section{MAIN PART}

In the classical approach to regional development, labour and financial flows are the most important components of the self-organization of the economic space. The migration of capital from rich to poor regions accelerates regional development and works to reduce regional inequalities. At the same time, substantial income differentials lead to migration flows of labour, usually from poor regions to rich ones, thus increasing regional differentiation. The integral effect of the migration of work force and capital provides prospects for the growth of regional economies and for the transformation of the economic space.

In order to analyse the impact of labour and financial flows on the transformation of the Russian Federation economic space, let us consider the dynamics of GRP in the NWFD regions for the period 2010-2013 and 2014 - 2018. In the first period, the average annual GRP growth for 10 regions was $3.6 \%$ (table. 1). At that, the resource regions had low growth rates - the Komi Republic - $1.65 \%$, the Arkhangelsk region $-1.05 \%$ and the Murmansk region - 
$0.12 \%$. The regions specializing in manufacturing industries had relatively high growth rates: Kaliningrad region $-4.45 \%$, Leningrad region $-4.12 \%$ and St. Petersburg $-4.95 \%$. During the stagnation of the economy, the average annual growth rate of GRP in Northwest Federal District declined to 1.3\%. At the same time, in the Komi Republic, GRP declined by an average of $2.6 \%$ per year, while in the Leningrad region it grew by $2.4 \%$. It should be noted that in the Central Federal District the economic dynamics had the same form - the average annual growth rate decreased from $3.3 \%$ to $1.2 \%$.

In order to assess the degree of correlation between the economic dynamics of the analysed periods, table 2 presents a typology of regions by GRP growth rates. The qualitative analysis does not reveal significant correlations between regional economic developments in the periods 2010 - 2013 and 2014 - 2018. Regions with a fairly strong economy (the Vologda, Novgorod, Leningrad and Kaliningrad regions and St. Petersburg) have reduced their growth rates by about half. Regions with relatively weak economies dropped to almost zero levels (the Republic of Karelia, the Pskov region). An improvement in economic dynamics occurred in the Murmansk and Arkhangelsk regions. These regions have a fairly powerful natural resource and industrial potential, which turned out to be in demand in the context of the implementation of federal programs for import substitution and development of the Arctic.

TABLE I. DYNAMICSOFREGIONAL INDICATORS, \%

\begin{tabular}{|c|c|c|c|c|c|c|}
\hline & \multicolumn{2}{|c|}{ GRP } & \multicolumn{2}{|c|}{ work force } & \multicolumn{2}{|c|}{ investments } \\
\hline & $\begin{array}{c}2010 \\
- \\
2013 \\
\end{array}$ & $\begin{array}{c}2014 \\
- \\
2018 \\
\end{array}$ & $\begin{array}{c}2010 \\
- \\
2013 \\
\end{array}$ & $\begin{array}{c}2014 \\
- \\
2018 \\
\end{array}$ & $\begin{array}{c}2010 \\
- \\
2013 \\
\end{array}$ & $\begin{array}{c}2014 \\
- \\
2018 \\
\end{array}$ \\
\hline $\begin{array}{c}\text { Northwest } \\
\text { federal district }\end{array}$ & 3,63 & 1,30 & $-0,20$ & $-0,06$ & 4,60 & 1,55 \\
\hline $\begin{array}{c}\text { The Karelia } \\
\text { Republic }\end{array}$ & 2,19 & 0,46 & $-1,47$ & $-1,17$ & $\begin{array}{c}10,0 \\
4 \\
\end{array}$ & $-2,53$ \\
\hline $\begin{array}{l}\text { The Komi } \\
\text { Republic }\end{array}$ & 1,65 & $-2,61$ & $-0,83$ & $-1,90$ & 8,92 & $\begin{array}{c}13,0 \\
8\end{array}$ \\
\hline $\begin{array}{c}\text { The } \\
\text { Arkhangelsk } \\
\text { region }\end{array}$ & 1,05 & 1,75 & $-1,0$ & $-1,63$ & $\begin{array}{c}11,3 \\
4\end{array}$ & $-1,11$ \\
\hline $\begin{array}{l}\text { The Vologda } \\
\text { region }\end{array}$ & 3,18 & 1,47 & $-1,01$ & $-1,98$ & 0,79 & 5,64 \\
\hline $\begin{array}{c}\text { The } \\
\text { Kaliningrad } \\
\text { region }\end{array}$ & 4,45 & 2,10 & 0,77 & $-0,14$ & $-4,28$ & 5,56 \\
\hline $\begin{array}{l}\text { The Leningrad } \\
\text { region }\end{array}$ & 4,12 & 2,43 & 0,00 & 0,39 & 2,84 & 7,01 \\
\hline $\begin{array}{l}\text { The Murmansk } \\
\text { region }\end{array}$ & 0,12 & 1,12 & $-1,04$ & $-1,91$ & 7,67 & 8,06 \\
\hline $\begin{array}{l}\text { The Novgorod } \\
\text { region }\end{array}$ & 4,04 & 1,73 & $-0,44$ & $-1,10$ & 1,10 & $-5,52$ \\
\hline $\begin{array}{l}\text { The Pskov } \\
\text { region }\end{array}$ & 3,13 & 0,13 & $-0,21$ & $-1,65$ & 9,13 & $-4,79$ \\
\hline $\begin{array}{c}\text { Saint- } \\
\text { Petersburg }\end{array}$ & 4,95 & 1,52 & 0,37 & 1,49 & 4,01 & 2,89 \\
\hline
\end{tabular}

A quantitative assessment of the relationship between regional growth rates during stagnation and the preceding period shows that the correlation coefficient is 0.41 , i.e. the relationship is rather weak, due to the large differences in the determinants. During the first period (2010 - 2013), there was a rebound in the export-commodity model. The dynamics was fading. For example, while the GRP in the Northwest
Federal District grew by $6.1 \%$ in 2011 , it fell to $3.8 \%$ in 2012 and $0.3 \%$ in 2013. The significant depreciation of the national currency and the adoption of an active import substitution policy in the face of rising geopolitical, economic and financial risks have failed to provide meaningful incentives to improve economic performance. As a result, the growth rates of the strong regions fell to $1-3 \%$ and those of the weak to almost zero, which contributed to further regional differentiation.

The quality of the economic space essentially depends on the level of its homogeneity. In the paper by E. Kolomak E.A. it is proposed to use the GRP per capita indicator to analyze the "economic" inequality, and the average per capita income - to analyze the "social" one [20].

Against the Russian background, the Northwest Federal District does not distinguish a high level of differentiation in the social and economic indicators of the regions. However, the deterioration in economic performance between 2014 and 2018 led to the increase in both economic and social inequality. For example, the ratio of the maximum to the minimum average per capita GRP increased from 2.8 in 2013 to 3.0 in 2018 , and the average per capita real income increased from 1.7 to 1.9 times.

TABLE II. TYPOLOGY OF REGIONS ACCORDING TO THE DYNAMICS OF GRP ( AVERAGE ANNUAL GROWTH OF GRP,\%)

\begin{tabular}{|c|c|c|c|c|}
\hline \multirow{2}{*}{$\begin{array}{l}2014- \\
2018\end{array}$} & \multicolumn{4}{|c|}{$2010-2013$} \\
\hline & Less 1,0 & $1,0-2,0$ & $2,1-3,0$ & more 3 \\
\hline less 0 & & $\begin{array}{l}\text { The Komi } \\
\text { Republic }\end{array}$ & & \\
\hline $0,1-1,0$ & & & $\begin{array}{c}\text { The } \\
\text { Karelia } \\
\text { Republic }\end{array}$ & $\begin{array}{c}\text { The Pskov } \\
\text { region }\end{array}$ \\
\hline $1,1-2,0$ & $\begin{array}{l}\text { The } \\
\text { Murmansk } \\
\text { region }\end{array}$ & $\begin{array}{c}\text { The } \\
\text { Arkhangelsk } \\
\text { region }\end{array}$ & & $\begin{array}{c}\text { The } \\
\text { Vologda, } \\
\text { Novgorod } \\
\text { regions, } \\
\text { Saint } \\
\text { Petersburg }\end{array}$ \\
\hline more 2,1 & & & & $\begin{array}{c}\text { The } \\
\text { Kaliningrad } \\
\text {, Leningrad } \\
\text { regions }\end{array}$ \\
\hline
\end{tabular}

A coefficient of variation, which is defined as the ratio of standard deviation to average, can be used to assess the degree of regional differentiation. Calculation of this indicator for estimating the heterogeneity of GRP growth rates for the periods 2010 - 2013 and 2014 - 2018 showed that it changed from $55.0 \%$ to $143.5 \%$. It is accepted in the statistics that if the coefficient of variation is less than $33 \%$, then the aggregate is considered homogeneous, if more than $33 \%$, then heterogeneous. Thus, the period of stagnation of the Russian economy is characterized by a significant increase in the difference in the growth rates of the regional economies, which leads to a further increase in the heterogeneity of the economic space of the NWFD.

Let's analyze the factors that contributed to this trend. The change in the number of work force by region is presented in table 1 . In a relatively favourable period for the Russian economy, 2010-2013 the decrease in the work force took place in almost all regions of the Northwest federal district, with the exception of the Kaliningrad region and St. Petersburg. During the period of economic stagnation, the processes of "pulling" the work force into prosperous regions 
accelerated significantly. The main centre of attraction is St. Petersburg, where the number of work force has increased every year by almost $1.5 \%$. The rest of the regions, with the exception of the Leningrad and Kaliningrad regions, are losing their working-age population at a high rate, which is due to both the high mortality rate of the working-age population and the migration outflow. The factors of this outflow are the insufficient supply of highly qualified jobs, as well as significant differences in the amount of average per capita social expenditures [21]. Thus, the acceleration of labour migration processes in conditions of stagnation of the economy to "prosperous" regions led to a further increase in the heterogeneity of the economic space.

Let us further consider the supply of the capital. As an indicator, we will consider the average annual increase in investment in fixed assets (Table 1). As in the case of GRP, the period of stagnation is characterized by an almost threefold decrease in the indicator for the NWFD as a whole. As for the regional aspect, it is distinguished by the preservation, and in some cases, an increase in the level of investment activity in strong regions and a significant decrease in weak ones. As a result, the ratio of the maximum (the Leningrad region) and minimum (the Pskov region) per capita investments increased from 3.3 times in 2013 to 5.1 times in 2018.

Thus, the most successful region at the stage of economic stagnation turned out to be the Leningrad region, in which economic growth was accompanied by both an increase in the work force and an increase in investment activity. In St. Petersburg, in the context of a low level of investment activity, an increase in the number of workers should be considered as the main factor of economic growth. The growth of capital supply at the stage of stagnation also took place in the Vologda, Kaliningrad and Murmansk regions.

We examined the impact on the quality of the economic space of traditional factors - the dynamics of the work force and the level of investment activity. In today's economy, the technological level of enterprises and their ability to produce innovative goods and services are emerging as major factors in regional development. In this regard, R\&D and their transformation into innovative goods and services must be considered as a fundamental factor in the sustainable development of regions in the long term [18]. The analysis of the dynamics of these factors in the context of economic stagnation is of particular interest. As for the technological level of enterprises, during the entire analyzed period (20102018) it remains approximately at the same level (Fig. 1). For clarity, the figure shows St. Petersburg and neighbouring regions specializing in the manufacturing industry. The methodology for calculating the indicator is based on a fairly inertial sectoral structure of the economy of the region, which is the main reason for the stability of the indicator. At the same time, due to the high level of investment activity, the Leningrad region was able to increase the share of high-tech and knowledge-based products in GRP and to reduce the gap with neighbouring regions.

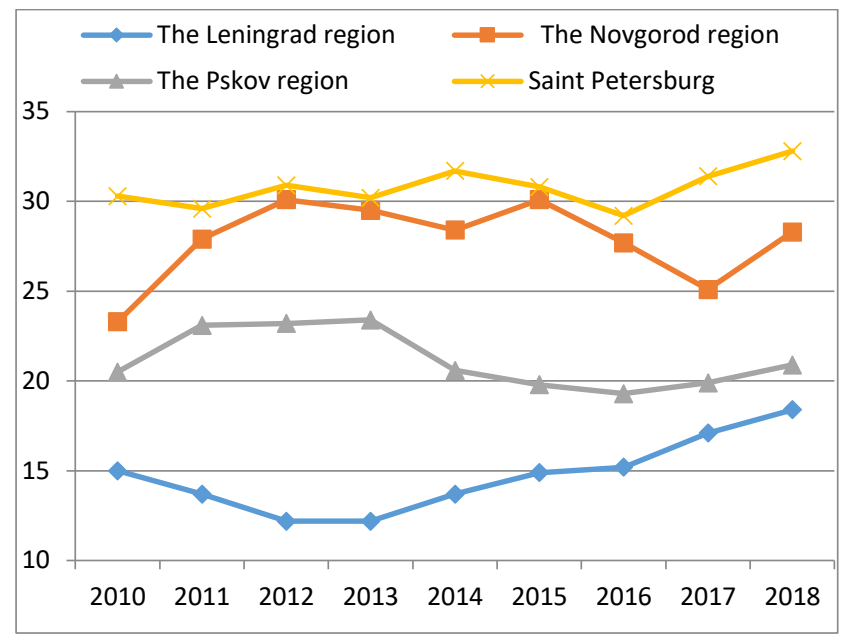

Fig.1. Share of high-tech and knowledge-intensive products in gross regional product, $\%$

An important factor for the sustainable development of the region's economies is the level of innovation activity of the organizations [22] (fig. 2). In the Russian Federation as a whole, $7.3 \%$ of technological innovation organizations were involved in 2016, which is significantly lower than in Estonia (20.8\%) and Germany (52.6\%) [23]. Thus, innovation activity in the regions represented is low. With the exception of Saint Petersburg, most of the NWFD regions have less than $10 \%$. During the period of stagnation of the economy, the level of innovation activity of enterprises in Saint Petersburg declined somewhat. At the same time, the indicator for other regions remained at a low but stable level.

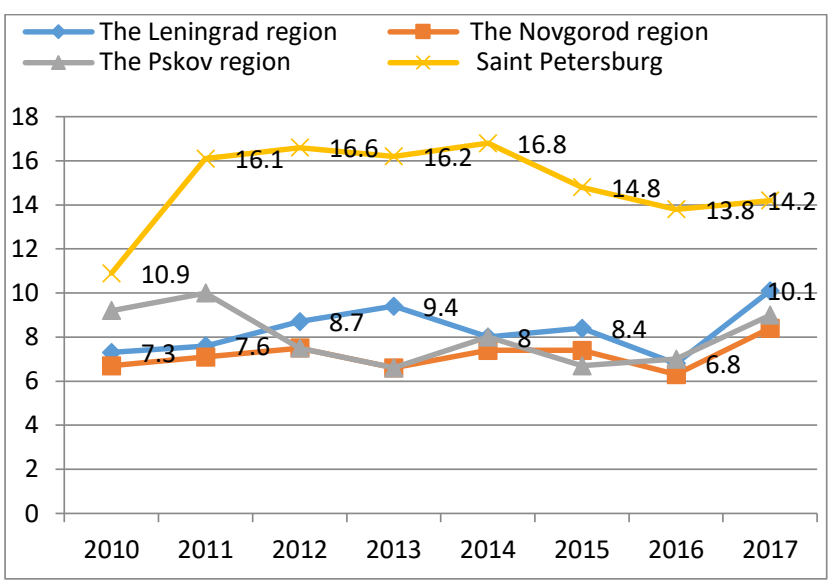

Fig.2. The percentage of organizations implementing technological innovations

Thus, the modern factors of regional development - the level of technology and innovation activity remained stable during the period of economic stagnation and did not influence the dynamics of the quality of the economic space. This situation is due to the low level of innovation of enterprises and, as a result, the predominant influence of traditional factors on the economic dynamics of the regions.

In recent years, the digital transformation of the economy has been seen as a driver of growth [24]. Digital processes have an integrated impact on regional development. The research shows a close relationship between digitalization and the level of investment and innovation activity [25]. The main goal of digitalization is to use the potential of information and communication technologies to create 
sustainable economic growth in the region, as well as to promote innovations [26]. In this regard, in the planning documents adopted in recent years, the priority is given to the development of the digital economy. Thus, the Strategy for Spatial Development of the Russian Federation for the period up to 2025 emphasizes the need to develop information and telecommunications infrastructure and eliminate the "digital inequality" of the constituent entities of the Russian Federation. In many respects, this task had been solved by the beginning of the period of economic stagnation. So, if in 2010 $61.7 \%$ of organizations in the Northwest Federal District had broadband access to the Internet, then in 2017 it was $88.6 \%$. At that, the Arkhangelsk region had the minimum value of the indicator $-83.2 \%$, and the maximum St. Petersburg $93.5 \%$. Thus, from the point of view of access to the Internet, we can speak of sufficient homogeneity of the economic space of the Northwest Federal District.

At the same time, it should be borne in mind that the access to the Internet is, first of all, an indicator of the development of information and communication infrastructure, which creates conditions for the development of business in the regions. At the same time, the impact of digitalization on the social and economic development of regions is determined by the level of use of ICT technologies by organizations in economic activities. To assess it, you can use the business digitalization index [27]. The distribution of this indicator in the regions of the Northwest Federal District is fairly homogeneous. At the same time, the maximum value of the indicator was 29 , and the minimum - 25. Thus, from the point of view of business digitalization, the economic space of the Northwest Federal District is quite homogeneous.

We have considered traditional and new factors of regional development. We included the size of the work force and the capital supply in the first group, and we included the level of innovation activity and the degree of digitalization of the business in the second group. While the first group of factors has a high level of differentiation and increases the heterogeneity of the Northwest Federal District economic space, the second group of factors is fairly evenly distributed among the regions. When assessing the impact of the second group of factors, it should be borne in mind that both the level of innovation and the level of digitization of the business of the Russian Federation rank in the middle of the world rankings.

On the basis of the analysis we can conclude that the mechanism of self-organization of the economic space of the North-West in the context of economic stagnation is not efficient enough. In order to identify the reasons for this situation, we study the degree of connectedness of the economic space of the North-West by means of correlation analysis method. Table 3 shows a matrix of correlation coefficients of production indices by type of economic activity "Manufacturing industries" for the analyzed periods (20102013 / 2014-2018). The matrix allows us to study the degree of interconnection of economic dynamics in the regions and, on this basis, draw a conclusion about the systemic properties of the economic space of the North-West.
TABLE III. CORRELATION COEFFICIENT MATRIX

\begin{tabular}{|c|c|c|c|c|}
\hline & $\begin{array}{c}\text { The } \\
\text { Leningra } \\
\text { d region }\end{array}$ & $\begin{array}{c}\text { The } \\
\text { Novgorod } \\
\text { region }\end{array}$ & $\begin{array}{c}\text { The } \\
\text { Pskov } \\
\text { region }\end{array}$ & $\begin{array}{c}\text { Saint } \\
\text { Petersburg }\end{array}$ \\
\hline $\begin{array}{c}\text { The } \\
\text { Leningrad } \\
\text { region }\end{array}$ & 1,00 & $0,73 / 0,27$ & $0,81 / 0,46$ & $0,88 / 0,81$ \\
\hline $\begin{array}{c}\text { The } \\
\text { Novgorod } \\
\text { region }\end{array}$ & $0,73 / 0,27$ & 1,00 & $0,89 /-$ & 0,33 \\
\hline $\begin{array}{c}\text { The Pskov } \\
\text { region }\end{array}$ & $0,81 / 0,46$ & $0,89 /-0,33$ & 1,00 & $0,57 / 0,19$ \\
\hline $\begin{array}{c}\text { Saint } \\
\text { Petersburg }\end{array}$ & $0,88 / 0,81$ & $0,57 / 0,19$ & $0,85 / 0,55$ & 1,00 \\
\hline
\end{tabular}

The greatest potential for enterprise-to-enterprise cooperatives is in the manufacturing sector, which continues to be the leading economic sector in most of the North-West regions. For example, in 2017, the share of manufacturing industries in the Novgorod region accounted for $38.9 \%$, in the Leningrad region - $29.7 \%$ of the GRP. Manufacturing industries in the GRP of the Pskov region and St. Petersburg have a slightly smaller share $-17.3 \%$ and $16.6 \%$, respectively.

Let us consider the degree of interconnection between the dynamics of manufacturing industries in St. Petersburg, as the macro-region centre, with other regions. The analysis shows that during the first period (2010-1013) a strong relationship takes place with the Leningrad Region (the correlation coefficient is 0.88) and with the Pskov region (the correlation coefficient is 0.85), with the Novgorod region the degree of relationship is average (the correlation coefficient is 0.57 ). There is a strong correlation between the dynamics of the processing industries of the regions because of the relative importance in their structure of such activities as food production, production of machinery and equipment, and production of electrical equipment. The similarity of the sectoral structure creates conditions for the development of cooperative ties between enterprises and for interregional interaction in general. The average level of correlation dependence of the dynamics of manufacturing industries in St. Petersburg and the Novgorod region is due to the large share of production of chemicals in the industry structure of the region. In the period 2010-2013 a rather strong relationship between the dynamics of manufacturing industries can also be noted between the Leningrad, Novgorod and Pskov regions. Thus, we can conclude that, at least within the North-West economic region in the period 2010-2013 there was a fairly strong interregional interaction in the manufacturing industry.

During the period of stagnation (2014-1018), the situation changed significantly. A strong relationship between the dynamics of manufacturing industries in St. Petersburg remained only with the Leningrad region (the correlation coefficient is 0.81 ), with the Pskov region it became medium (the correlation coefficient is 0.55 ), and with the Novgorod region, it is weak (the correlation coefficient is 0.19). Thus, the results of the correlation analysis indicate a significant decrease in the level of interregional interaction between St. Petersburg, Leningrad, Novgorod and Pskov regions during the period of economic stagnation. 


\section{CONCLUSION}

So, our research indicates a fairly strong impact of economic stagnation in the period 2014-2018 on the quality of the economic space of the Northwest Federal District. A significant decrease in the growth rates of GRP and investments in fixed assets was accompanied by a significant increase in their interregional differentiation, which led to a further increase in the heterogeneity of the economic space. A sharp decline in the indicators of "weak" regions has led to an increase in the trend of "pulling" the population into rather prosperous regions, which creates a multiplier effect of the growth of differentiation in the level of socio-economic development of the constituent entities of the Federation. A significant negative aspect in the quality of the economic space is also brought about by a significant decrease in the level of interregional interaction in the context of economic stagnation.

\section{REFERENCES}

[1] N.D. Matrusov, Regional forecasting and regional development of Russia, Moscow, 1995, 221 p.

[2] S.V. Naumov, A.A. Ermolenko, "The category of place in the Modern Theory of economic space", Spatial Economics, vol. 16 (2), 2020, pp. $101-$ 123. DOI: https://dx.doi.org/10.14530/se.2020.2.pp. 101-123.

[3] L.M. Averina, D.V. Sirotin, "Assessment of spatial effects of innovation activity in the industrially developed regions of the Russian Federation", Economy of the region, vol. 16 (1), 2020, pp. 268-282. DOI: https://doi.org/10.17059/2020-1-20.

[4] M.A Nikolaev,. M.Ju. Mahotaeva, "The role of the territorial factor in economic dynamics", Economist, no. 3, 2015, pp.42-49.

[5] S.V. Kuznecov, N.M. Mezhevich, "Transformation of the structure of the SZFO Economic Space as a prerequisite for a new model of interaction between the state and business", Management consulting, no. 6, 2016, pp. 50-61.

[6] S.V. Stepanova, O.V. Tolstoguzov, "Transformation of the Regional Socio-economic System: a Conceptual Model”, Proceedings of the Karelian Scientific Center of the Russian Academy of Sciences, no.5, 2013, pp. 1221.

[7] N.T. Avramchikova, "Theoretical aspects of assessing the quality of economic space, regional economy: theory and practice 35 (266), 2012, pp $2-13$.

[8] A.G. Granberg, Fundamentals of the regional economy. textbook for universities Moscow.: GU VShJe, 2000, 495 p.

[9] R. Huggins, P. Thompson, "Human agency, entrepreneurship and regional development: a behavioural perspective on economic evolution and innovative transformation", ENTREPRENEURSHIP AND REGIONAL DEVELOPMENT, vol. $32 \quad(7-8), \quad 2020, \quad$ pp. 573-589. DOI: $10.1080 / 08985626.2019 .1687758$.

[10] O.V. Kozhevina, "Control of the spatial changes in order to ensure economic security”, Upravlenie, no.1, 2020, pp. 141-149. DOI 10.26425/2309-3633-2020-1-141-149.

[11] D.A. Izotov, "Inflow of foreign direct investments in Russia's regions: potential and risk factors", Economic and Social Changes: Facts, Trends, Forecast, vol. 12 (2), 2019, pp. 56-72. DOI: 10.15838/esc.2019.2.62.3.

[12] M. A. Nikolaev, M. Yu. Makhotaeva, O. A. Bakumenko, D. P. Malyshev, "Sustainable Development Factors of the Economy Of Regions In Russia", The European Proceedings of Social \& Behavioural Sciences EpSBS, vol. LXXVII, 2019, pp. 398-406.

[13] G. Kaletnik, S. Lutkovska, "Innovative Environmental Strategy for Sustainable Development", EROPEAN JOURNAL OF SUSTAINABLE DEVELOPMENT, vol. $9 \quad$ (2), 2020, pp. 89-98. DOI: 10.14207/ejsd.2..v9n2p89.

[14] E.V. Balatsky, N.A. Ekimova, "Modern ways to boost economic growth in regions", Economic and Social Changes: Facts, Trends, Forecast, vol. 13 (3), 2020, pp. 74-92. DOI: 10.15838/esc.2020.3.69.6.
[15] B. Patrizio, S. Labory, "Regional industrial policy for the manufacturing revolution: enabling conditions for complex transformations". CAMBRIDGE JOURNAL OF REGIONS ECONOMY AND SOCIETY, vol. 12 (2), 2019, pp. 233-249.

[16] I.V. Naumov, Ju.V. Dubrovskaja, E.V. Kozonogova,"Digitalization of industrial production in the regions of Russia. Spatial communication", the region's Economy, vol. 16 (3), 2020, pp. 896-910. DOI: https://doi.org/10.17059/ekon.reg.2020-3-17.

[17] T.V. Miroljubova, T.V Karlina, R.S. Nikolaev, "Digital economy: problems of identification and changes in the regional economy. economy of the region, vol.16 (2), 2020, pp. 377-390. DOI: http://doi.org/10.17059/2020-2-4.

[18] A.A. Rumyantsev, "Research and Innovation Activity in the Region as a Driver of Its Sustainable Economic Development", Economic and Social Changes: Facts, Trends, Forecast, vol. 11 (2), 2018, pp. 84-99. DOI: 10.15838/esc.2018.2.56.6.

[19] D. Douglas, D. Radicic, Network additionality and policy mix of regional, ECONOMICS OF INNOVATION AND NEW TECHNOLOGY. DOI: $10.1080 / 10438599.2020 .1789277$

[20] E.A. Kolomak, "Interregional Inequality of Russia: economic and social aspects", spatial economics, no.1, 2010, pp. 26-35.

[21] M.A. Nikolaev, M.Yu. Makhotaeva, D.P. Malyshev, "Sustainable Development Assessment of the NWFD Regions", Digital Future Economic Growth, Social Adaptation, and Technological Perspectives. Part of the Lecture Notes in Networks and Systems.- LNNS, vol. 111. pp. 809-817. DOI: doi.org/10.1007/978-3-030-39797-5_79.

[22] N. Shashlo, G. Petruk, A. Korostelev, "Determinants of integration interaction among the subjects of the entrepreneurial innovation ecosystem of macro region", AMAZONIAINVESTIGA, 7 (13), 2018, pp. 351-363.

[23] I.V. Lutoshkin, A.A. Paramonova, "Analysis of the impact of siphon technologies on the national economy", Scientific and Technical Bulletin of SPbSPU. Economic sciences, vol. 12 (4), 2019, pp. 20-31.

[24] M.V. Vlasov, "Sustainability of a regional investment strategy: factors of a digital economy", AMAZONIA INVESTIGA, vol. 8 (23), 2019, pp.140147.

[25] V. Tsirenshchikov. "Digitalization of European Economy", CONTEMPORARY EUROPE-SOVREMENNAYA EVROPA, 3, 2019, pp.104-113.

[26] G. I. Abdrahmanova, K. O. Vishnevskij, G. L. Volkova, L. M. Gohberg Indicators of the financial economy: 2018: statistical collection, National Research University «Higher School of Economics», Moscow, 2019, 248 p. 